\title{
The effect of drilling parameters for surface roughness in drilling of AA7075 alloy
}

\author{
Nafiz Yaşar ${ }^{1, *}$, Mehmet Boy ${ }^{1}$, and Mustafa Günay ${ }^{2}$ \\ ${ }^{1}$ Karabük University, TOBB Vocational School, Bilimler Meslek Yüksekokulu, Demir Çelik \\ Kampüsü, 78050, Karabük, Turkey \\ ${ }^{2}$ Karabük University, Department of Mechanical Engineering, Balıklarkayası, Mevkii, 78050, \\ Karabük, Turkey
}

\begin{abstract}
AA7075 aluminum alloy has been very popular significantly interest in the production of structural components in automotive and aviation applications due to its high strength, low density, good plasticity and better machinability comparable to many metals. Particularly, final products must have uniformly high quality to ensure essential safety standards in the aircraft industry. The optimization of hole quality which can variable according to tool geometry and drilling parameters is important in spite of high machinability rate of AA7075 alloy. In this study, the effects of drilling parameters on average surface roughness (Ra) has been investigated in drilling of AA7075 with tungsten carbide drills. Machining experiments were performed with three different drill point angles and three different levels of cutting parameters (feed rate, cutting speed). The effects of drilling parameters on thrust force has been determined with ANOVA in $\% 95$ confidence level. Feed rate was determined as the most important factor on Ra according to ANOVA results. Moreover, it was shown that increasing feed rate leads to increase of $\mathrm{Ra}$ while increasing drill point angle leads to decrease of Ra. The optimum surface roughness was obtained with point angle of $130^{\circ}$, cutting speed of $40 \mathrm{~m} / \mathrm{min}$ and feed rate of $0.1 \mathrm{~mm} / \mathrm{rev}$, thereby the validity of optimization was confirmed with Taguchi method.
\end{abstract}

\section{Introduction}

Aluminum and its many alloys are commonly used in aerospace, computer and medical industries due to their lower weight, height strength and electrical, thermal conductivity [1]. Machining of aluminum became an important research manner because of its behavior during its machining. Tool wear, burr formation and hole surface quality are the most common problems in drilling of aluminum and its alloys. These materials adhere to cutting tool due to their smearing properties. This situation cause to change in cutting tool geometry. Thus, thrust force and surface roughness increase, too. The surface of machined part is one of the most important criteria in terms of quality. The cutting parameters used

\footnotetext{
* Corresponding author: nafizyasar@karabuk.edu.tr
} 
during machining of materials are important factors affecting surface accuracy [2]. Surface quality can be obtained by right choice of machining parameters.

Cutting force is known as related with tool-chip contact length in machining process. According to that adhering chip on tool change tool nose geometry. Thus, that cause to a change of force on cutting tool. Although aluminum is a ductile material, machining of these alloys will affect tool life more than expected. In recent years, many research are done in order to measure the force on tool in adequate accuracy. The forces on tool is an important part of machining. Measuring of cutting forces is useful in optimizing of tool design and necessary for scientific analysis of cutting [3].

Drilling of hole is one of the most common machining processes applied to aluminum alloys [4]. Drilling is the most problematic machining process in removal of chips from cutting region. The leading reason is that chip forming is in closed area and not seen [5]. Rivero et al. described an experimental research study on machinability in the dry drilling of aluminum alloys (AA7075-T6) and on the potential of the new design of tools and coatings. Dry drilling tests were performed using uncoated drills and two different coatings produced by means of an arc evaporation PVD process. Experiments consisted of machining with a $10 \mathrm{~mm}$ diameter three-edged drill to produce $25 \mathrm{~mm}$ deep holes. Tool wear evolution and burr size were analyzed, as well as the impact of the process parameters on torque, power, feed force and tool temperature. The authors stated that drilling of aluminum alloys effectively in dry condition is possible [6]. Kilıçkap [7] investigated the influence of cutting parameters, such as cutting speed and feed rate, and point angle on burr height and surface roughness produced when drilling Al-7075. All tests were run without coolant at three different levels of cutting speed, feed rate and point angle. The orthogonal array, signal-to-noise ratio, and analysis of variance (ANOVA) were employed to investigate the optimal drilling parameters of AA7075. The optimization results showed that the combination of low cutting speed, low feed rate, and high point angle is necessary to minimize burr height. The best results of the surface roughness were obtained at lower cutting speed and feed rates while at higher point angle. The predicted values and measured values are quite close to each other. The author indicated that the developed models can be effectively used to predict the burr height and the surface roughness on drilling of AA7075. Kannan et al. [8] observed that AA7075 alloy has less burring when comparing with pure aluminum in their study. Hanyu et al. [9] studied that shaft tools with new coatings were applied to dry and semi-dry machining of highly adherent aluminum alloys whose efficient means of dry machining have not yet been established for. In comparison to the case of conventional diamond coatings with rough surfaces, more than four times longer durability of drills was realized in perfectly dry condition. In the case of minimum quantity of lubricant condition, the lifetime was found again to be more than four times longer and successfully achieved the largest improvement of diamond-coated drills ever reported in semi-dry condition. Kurt et al. investigated the effects of cutting parameters on drilling temperature, cutting force and surface roughness in drilling of AA2024 with diamond like carbon coated drills. In their study, it was determined that the most significant parameters on surface quality is feed rate and drill diameter. Also, author observed that the change in feed rate and drill diameter affect average surface roughness considerably in high cutting speed [10].

It is noticed that there is not sufficient study about 7000 series of aluminum alloys whose usage is increasingly spreading. In this study, the effects of drilling parameters (point angle, cutting speed and feed rate) on thrust force were examined in dry drilling of AA7075 aluminum alloy. 


\section{Material and method}

In this study, drilling processes of AA7075 alloy in three different levels of point angle $\left(120^{\circ}, 130^{\circ}\right.$ and $\left.140^{\circ}\right)$, cutting speed $(40,80$ and $120 \mathrm{~m} / \mathrm{min})$ and feed rate $(0.05,0.1$ and $0.15 \mathrm{~mm} / \mathrm{rev}$ ) were performed in CNC vertical drilling machine (Johnford VMC-550). Karcan branded tungsten carbide drills were used as cutting tool in experiments. Drills had diameters of $5 \mathrm{~mm}$, helical angle of $30^{\circ}$ and geometry of 2 cutting edge. Each drilling process was repeated three times and evaluations were done by taking arithmetic average of drilling outputs. The drilling parameters (factors) were given in Table 1.

Table 1. Drilling parameters and levels

\begin{tabular}{|c|c|}
\hline Factors & Levels \\
\hline Point angle, $\mathrm{P}\left(^{\circ}\right)$ & $120-130-140$ \\
\hline Cutting speed, $\mathrm{V}(\mathrm{m} / \mathrm{min})$ & $60-100-140$ \\
\hline Feed rate, $\mathrm{f}(\mathrm{mm} / \mathrm{rev})$ & $0.05-0.1-0.15$ \\
\hline
\end{tabular}

Proper number of revolutions according to cutting speed by using speed head were obtained due to the fact that $\mathrm{CNC}$ milling machine in experiments has $6000 \mathrm{rev} / \mathrm{min}$ as a maximum number of revolution. Surface roughness (Ra) values in drilling experiments were measured by Mahr Perthometer M300 device. The experimental setup for drilling tests was given in Figure 1.

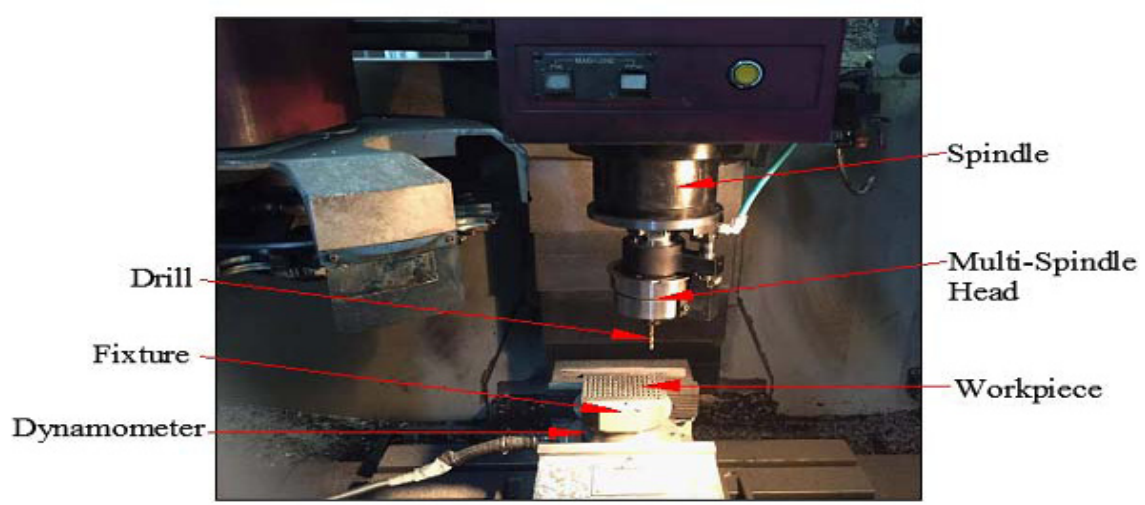

Fig. 1. The experimental setup for drilling tests.

Three different levels of feed rate, cutting speed and point angle were chosen as drilling parameters in experimental design according to full factorial. The levels of these parameters were determined by considering cutting tool company and other studies about AA7075 in literature. In the light of experimental results, the effects of parameters on Ra were determined by analysis of variance (ANOVA) performed with 95\% confidence level. Finally, drilling parameters for average surface roughness were optimized based on Taguchi method according to $\mathrm{L}_{27}$ orthogonal array. Therefore, the-smaller-the-better approach were applied due to desire of average surface roughness (Ra). The drilling parameters giving optimum surface roughness were determined in optimization study according to $\mathrm{S} / \mathrm{N}$ ratio. In the Eq. (1), $\mathrm{n}$ and $\mathrm{y}$ shows the number of experiments and performance characteristic, respectively [11].

$$
S / N=-10 \log \left(\frac{1}{n} \sum_{i=1}^{n} y_{i}^{2}\right)
$$




\section{Results and Discussion}

\subsection{Analysis of surface roughness $(\mathrm{Ra})$}

Captions should be typed in 9-point Times. They should be centred above the tables and The variations of $\mathrm{Ra}$ values according to drilling parameters in experimental results were given in Figure 2. Ra values increased with increasing feed rate when examining of graph and this result show similar tendency with literature. The reason of that can be explained by increasing chip volume with increasing feed rate. Because, increasing feed rate causes high thrust force, low shear angle and thick chip formation $[12,13]$.

It is known that low temperatures cause BUE formation in machining of aluminum and its alloys due to having multiple phases. Figure 2 show that increasing of Ra values with increasing point angle can be referred to that tool-chip contact area decrease with increasing point angle. Decreasing tool-chip contact area leads to decrease in temperature because it causes less friction. Increase of BUE can be explained with decreasing temperature [13]. Increasing $\mathrm{Ra}$ value can be referred that BUE formation is unstable form.

As literature examining, it is known that $\mathrm{Ra}$ values decrease with increasing cutting speed. However, previous studies were performed in lower cutting speeds. It is seen from Figure 2 that $\mathrm{Ra}$ values
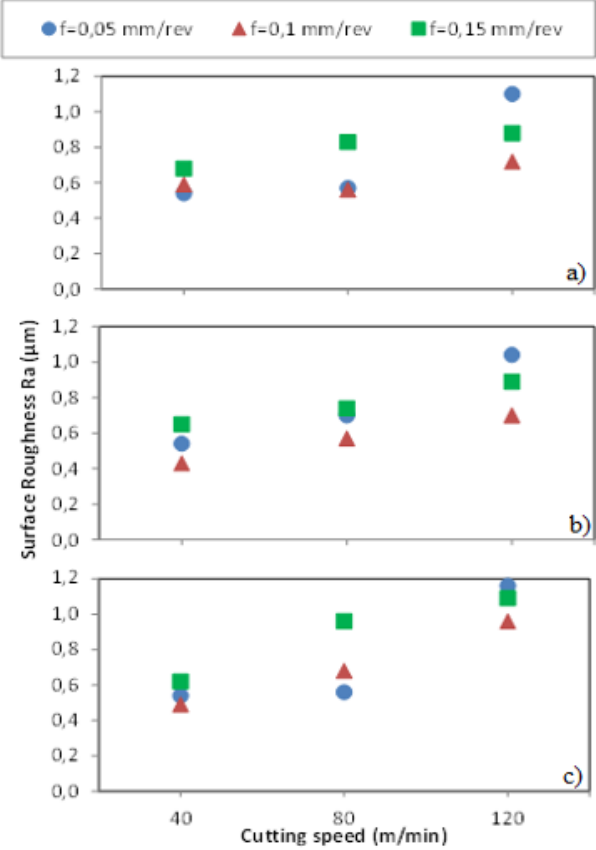

Fig. 2. The variation of $\mathrm{Ra}$ according to drilling parameters a) $120^{\circ}$, b) $130^{\circ}$, c) $140^{\circ}$. increase with increasing cutting speed. Increase in cutting speed is known as important parameter on increasing chatter effecting $\mathrm{Ra}$ values negatively in drilling operations [14]. Amplitude increase on torque is seen with increasing cutting speed by examining torque graphs obtained during drilling operations (Figure 3). It can be said that these amplitudes generated in this torque values cause increase in Ra values.

The smallest Ra value was obtained as $0.43 \mu \mathrm{m}$ (feed rate of $0.1 \mathrm{~mm} / \mathrm{rev}$, cutting speed of $40 \mathrm{~m} / \mathrm{min}$ and point angle of $130^{\circ}$ ) while highest value was obtained as $1.16 \mu \mathrm{m}$ (feed rate of $0.05 \mathrm{~mm} / \mathrm{rev}$, cutting speed of $120 \mathrm{~m} / \mathrm{min}$ and point angle of $140^{\circ}$ ).

Additionally, analysis of variance (ANOVA) results performed on the $95 \%$ confidence level in order to determine the effects of factors on the Ra are given in Table 2. Here, the probability $(\mathrm{P})$ values indicating the importance level of each factor, degree of freedom (DF), the sum of squares (SS), F-ratio and the percent contribution ratio (PCR) is shown. P value should be lower than 0.05 in $95 \%$ confidence level in order to determine that any factor acting on the force is effective on it. Table 2 indicates that the most effective factor on the surface roughness is cutting speed with $62.03 \%$ PCR. The feed rate and point angle have effect on thrust force with $13.68 \%$ and $3.40 \%$ PCR, respectively. According to that, statistical analysis results confirm the experimental results. 


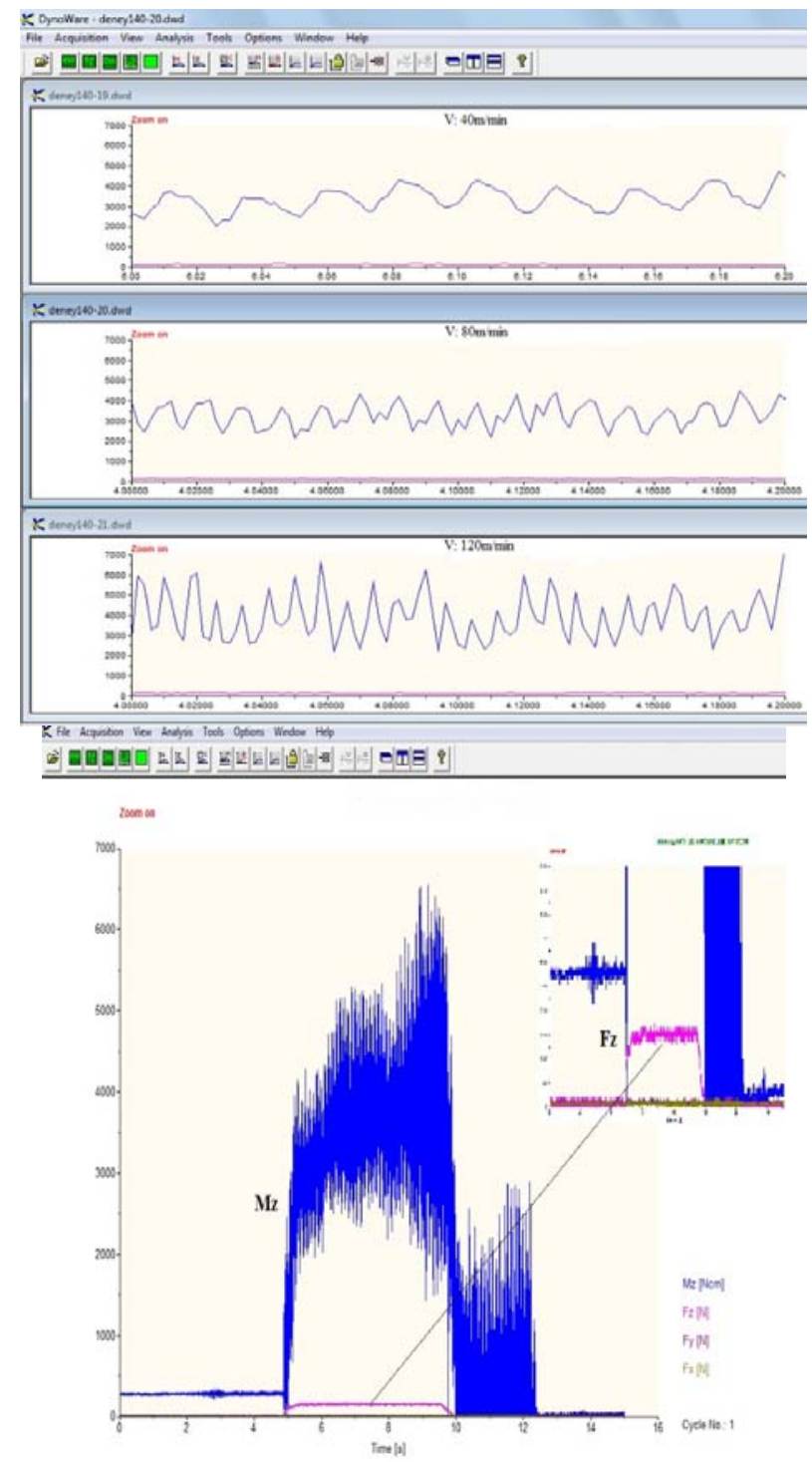

Fig. 3. The variation of $\mathrm{Mz}$ and Fz.

Table 2. ANOVA result for Ra

\begin{tabular}{|l|c|c|c|c|c|c|}
\hline Factor & DF & SS & MS & F-ratio & P & \%PCR \\
\hline$\Phi\left(^{\circ}\right)$ & 2 & 0.03823 & 0.019115 & 4.75 & 0.044 & 3.40 \\
\hline $\mathrm{V}(\mathrm{m} / \mathrm{min})$ & 2 & 0.69543 & 0.347715 & 86.37 & 0.000 & 62.03 \\
\hline $\mathrm{f}(\mathrm{mm} / \mathrm{rev})$ & 2 & 0.15334 & 0.076670 & 19.04 & 0.001 & 13.68 \\
\hline$\varphi^{*} \mathrm{~V}$ & 4 & 0.04624 & 0.011559 & 2.87 & 0.095 & 4.12 \\
\hline$\varphi^{*} \mathrm{f}$ & 4 & 0.02086 & 0.005215 & 1.30 & 0.349 & 1.87 \\
\hline $\mathrm{V}^{*} \mathrm{f}$ & 4 & 0.13486 & 0.033715 & 8.37 & 0.006 & 12.03 \\
\hline Error & 8 & 0.03221 & 0.004026 & & & 2.87 \\
\hline Total & 26 & 1.12116 & & & & 100 \\
\hline $\mathrm{R}^{2}=98.4 \%$ & & & & \\
\hline
\end{tabular}


The surface roughness values were obtained from drilling experiments and their $\mathrm{S} / \mathrm{N}$ ratios calculated according to Eq. (1) are given in Table 3.

Table 3. Surface roughness and their $\mathrm{S} / \mathrm{N}$ ratios.

\begin{tabular}{|c|c|r|r|r|r|r|r|r|r|r|c|}
\hline $\begin{array}{c}\text { Exp. } \\
\text { no }\end{array}$ & $\begin{array}{c}\text { Point } \\
\text { angle }\end{array}$ & $\begin{array}{c}\text { Cutting } \\
\text { speed }\end{array}$ & $\begin{array}{c}\text { Feed } \\
\text { rate }\end{array}$ & Ra & $\begin{array}{c}\text { S/N } \\
\text { ratio }\end{array}$ & $\begin{array}{c}\text { Exp. } \\
\text { no }\end{array}$ & $\begin{array}{c}\text { Point } \\
\text { angle }\end{array}$ & $\begin{array}{c}\text { Cutting } \\
\text { speed }\end{array}$ & $\begin{array}{c}\text { Feed } \\
\text { rate }\end{array}$ & Ra & $\begin{array}{c}\text { S/N } \\
\text { ratio }\end{array}$ \\
\hline 1 & 1 & 1 & 1 & 0.540 & 5.3521 & 15 & 2 & 2 & 3 & 0.740 & 2.6153 \\
\hline 2 & 1 & 1 & 2 & 0.590 & 4.5829 & 16 & 2 & 3 & 1 & 1.040 & -0.3406 \\
\hline 3 & 1 & 1 & 3 & 0.680 & 3.3498 & 17 & 2 & 3 & 2 & 0.700 & 3.0980 \\
\hline 4 & 1 & 2 & 1 & 0.570 & 4.8825 & 18 & 2 & 3 & 3 & 0.890 & 1.0122 \\
\hline 5 & 1 & 2 & 2 & 0.560 & 5.0362 & 19 & 3 & 1 & 1 & 0.540 & 5.3521 \\
\hline 6 & 1 & 2 & 3 & 0.830 & 1.6184 & 20 & 3 & 1 & 2 & 0.490 & 6.1960 \\
\hline 7 & 1 & 3 & 1 & 1.100 & -0.8278 & 21 & 3 & 1 & 3 & 0.620 & 4.1521 \\
\hline 8 & 1 & 3 & 2 & 0.720 & 2.8533 & 22 & 3 & 2 & 1 & 0.560 & 5.0362 \\
\hline 9 & 1 & 3 & 3 & 0.880 & 1.1103 & 23 & 3 & 2 & 2 & 0.680 & 3.3498 \\
\hline 10 & 2 & 1 & 1 & 0.540 & 5.3521 & 24 & 3 & 2 & 3 & 0.960 & 0.3545 \\
\hline 11 & 2 & 1 & 2 & 0.430 & 7.3306 & 25 & 3 & 3 & 1 & 1.160 & -1.2891 \\
\hline 12 & 2 & 1 & 3 & 0.650 & 3.7417 & 26 & 3 & 3 & 2 & 0.960 & 0.3545 \\
\hline 13 & 2 & 2 & 1 & 0.700 & 3.0980 & 27 & 3 & 3 & 3 & 1.090 & -0.7485 \\
\hline 14 & 2 & 2 & 2 & 0.570 & 4.8825 & & & & & & \\
\hline
\end{tabular}

For optimizing of process factor, $\mathrm{S} / \mathrm{N}$ ratios are considered in Taguchi optimization method. The highest $\mathrm{S} / \mathrm{N}$ ratio shows the optimum level of parameters according to thesmaller-the-better approach. Moreover, distribution of calculated average $\mathrm{S} / \mathrm{N}$ ratios according to parameters for $\mathrm{Ra}$ is given in Table 4. It is seen that the most important parameter on $\mathrm{Ra}$ is cutting speed $(\mathrm{V})$ when examining maximum and minimum points of $\mathrm{S} / \mathrm{N}$ ratios in Table 4. Consequently, the optimum levels of parameters were determined as $\mathrm{P} 2$, V1 and $\mathrm{f} 2$ according to calculated $\mathrm{S} / \mathrm{N}$ ratios as can be seen from Table 4.

Table 4. Response table of $\mathrm{S} / \mathrm{N}$ ratios for surface roughness

\begin{tabular}{|l|c|c|c|c|}
\hline \multirow{2}{*}{ Factors } & \multicolumn{4}{|c|}{ S/N ratios } \\
\cline { 2 - 5 } & Level 1 & Level 2 & Level 3 & Max.-Min. \\
\hline Point angle & 3.1064 & $3.4211^{*}$ & 2.5287 & 0.8925 \\
\hline Cutting speed & $5.0455^{*}$ & 3.4304 & 0.5803 & 4.4653 \\
\hline Feed rate & 2.9573 & $4.1871 *$ & 2.2753 & 2.2753 \\
\hline *Optimum levels of parameters \\
\hline
\end{tabular}

Average of drilling experiment result performed at optimal levels of factors are evaluated by Eq. (2) to forecast the mean for the improvement conditions. Eq. (1) which is the expression of calculated surface roughness $(\mathrm{Ra})$ is derived from Eq. (3).

$$
\begin{array}{r}
\eta_{G}=\bar{\eta}_{G}+\left(\bar{P}_{O}-\bar{\eta}_{G}\right)+\left(\bar{V}_{O}-\bar{\eta}_{G}\right)+\left(\bar{f}_{O}-\bar{\eta}_{G}\right) \\
R a_{c a l}=10^{-\eta_{G} / 20}
\end{array}
$$


Where, $\eta_{G}$ is the $\mathrm{S} / \mathrm{N}$ ratio calculated at optimal level of factors $(\mathrm{dB}), \bar{\eta}_{G}$ is the mean S/N ratio of all parameters $(\mathrm{dB}), \bar{P}_{O}, \bar{V}_{O}$ and $\bar{f}_{O}$ are the mean $\mathrm{S} / \mathrm{N}$ ratio when point angle, cutting speed and feed rate are at optimum levels, respectively and $\mathrm{Ra}_{\mathrm{cal}}$ is the calculated value. Consequently, $\eta_{\mathrm{G}}$ and $\mathrm{Ra}_{\text {cal }}$ for optimum drilling parameters were determined as $6.9800 \mathrm{~dB}$ and 0.44 , respectively. Lastly, confirmation experiments is done by using the optimum drilling parameters after the determination of these factors for $\mathrm{Ra}$ and thus reliability of the optimization has been confirmed. However, the $\mathrm{Ra}(0.43 \mu \mathrm{m})$ and $\mathrm{S} / \mathrm{N}$ ratio were obtained for surface roughness is very close to the predicted or calculated values. Thus, there is no need to carry out confirmation experiments if the drilling parameters found with the optimization procedure are included in the drilling conditions within the Taguchi experimental design.

\section{Conclusion}

In this study, the effects of drilling parameters (point angle, cutting speed and feed rate) on Ra were examined in dry drilling of AA7075 aluminum alloy based on Taguchi method. It was determined that Ra values increased with increasing feed rate in drilling of AA7075 aluminum alloys. The most effective factor on the Ra is cutting speed with $62.03 \%$ PCR according to ANOVA results. The smallest Ra value was obtained as $0.43 \mu \mathrm{m}$ (feed rate of $0.1 \mathrm{~mm} / \mathrm{rev}$, cutting speed of $40 \mathrm{~m} / \mathrm{min}$ and point angle of $130^{\circ}$ ) while highest value was obtained as $1.16 \mu \mathrm{m}$ (feed rate of $0.05 \mathrm{~mm} / \mathrm{rev}$, cutting speed of $120 \mathrm{~m} / \mathrm{min}$ and point angle of $140^{\circ}$ ). The results obtained have shown one more time that Taguchi method is a design and analysis of experiment technique that can be applied in machining investigates successfully.

\section{References}

1. ASM Handbook, (1999), Machining, Printed in USA, Volume: 16, 761-804.

2. B.J. Griffiths, Surface Integrity and Functional Performance, (Manufacturing Surface Technology, Penton Press, London, 2001)

3. A. Çakır, Investigation of Cutting Parameters During Drilling Operations of Al 7075 and Al 6013 Aluminum Materials (in Turkish), (Gazi University Graduate School of Natural and Applied Sciences, Ankara, Turkey, 2009)

4. J. Kim, D.A. Dornfeldd, Trans ASME, 124, 192-198, (2002)

5. M. Akkurt, Cutting Methods and Machine Tools (in Turkish), (Birsen Publishing House, Istambul, 1998)

6. A. Rivero, G. Aramendi, S. Herranz, L.N. Lopez de Lacella, Int J Adv Manuf Technol 28 (1), 1-11, (2006)

7. E. K1lıçkap, Int J Adv Manuf Technol 49, 911-923, (2010)

8. I. Suresh Kannan, A. Ghosh, Procedia Materials Science 5, 2615-2621, (2014)

9. H. Hanyu, S. Kamiya, Y. Murakami, M. Saka, Surface and Coatings Technology, 173174, 992-995, (2003)

10. M. Kurt, Y. Kaynak, B. Bakır, U. Köklü, G. Atakök, L. Kutlu, Proceedings of the International Advanced Technologies Symposium - IATS'09, (Karabuk University, 2009)

11. M. Günay, J Fac Eng Archit Gaz, 28 (3), 437-444 (2013) 
12. C. Çakır, Principles of Modern Machining (in Turkish), (Nobel Publishing, Ankara, 2006)

13. E.M. Trent, Metal Cutting, (Butterworths Pres, London, 1989)

14. M. Kurt, Y. Kaynak, E. Bagci, Int J Adv Manuf Technol 37, 1051-1060 (2008)

15. M. Boy, I. Ciftci, M. Gunay, F. Ozhan, Materials and Technology 49(5), 765-772, (2015) 